\title{
Heritabilities and Genetic Correlations of Body Condition Score and Calving Interval with Yield, Somatic Cell Score, and Linear Type Traits in Brown Swiss Cattle
}

\author{
R. Dal Zotto, ${ }^{1}$ M. De Marchi, C. Dalvit, M. Cassandro, L. Gallo, P. Carnier, and G. Bittante \\ Department of Animal Science, University of Padova, Viale dell'Università 16, 35020 Legnaro, Padova, Italy
}

\begin{abstract}
This study aimed to estimate genetic parameters for body condition score (BCS), calving interval (CI), somatic cell score (SCS), yield, and linear type traits for the Italian Brown Swiss cattle population. A total of 32,359 records of first-parity lactating cows were collected from 2002 to 2004 in 4,885 dairy herds. The pedigree file included 96,661 animals. Multiple-trait animal models were analyzed using REML to estimate (co)variance components without repeated observations on traits. The estimated heritability was 0.15 for BCS, 0.05 for CI, and 0.06 for SCS, and ranged from 0.09 to 0.14 for test-day yield traits and from 0.07 to 0.32 for linear type traits. The genetic correlations of CI with yield and most linear type traits were positive, whereas the correlation between CI and BCS was negative $(-0.35)$. For type traits, BCS showed, in general, a moderately negative genetic correlation except for strength, pastern, and heel height. The genetic correlation of CI or BCS with SCS was moderately low but favorable (0.19 and -0.26 , respectively). The estimated correlations indicated that selection for greater yield and type traits can exert unfavorable effects on the reproductive ability of cows. To counterbalance these effects and to carry out early prediction of breeding values of bulls for fertility, inclusion of BCS in the breeding program is advisable.
\end{abstract}

Key words: body condition score, fertility, heritability, genetic correlation

\section{INTRODUCTION}

The substantial genetic improvement obtained in milk yield has caused a decline in the reproductive efficiency of dairy cattle (Grosshans et al., 1997; Dematawewa and Berger, 1998; Castillo-Juarez et al., 2000) and has increased susceptibility to several diseases as

Received April 13, 2007.

Accepted August 30, 2007.

${ }^{1}$ Corresponding author: riccardo.dalzotto@unipd.it well as the risk of culling due to reproductive or health disorders and other abnormalities (Simianer et al., 1991; Dematawewa and Berger, 1998; Rogers et al., 1999; Lassen et al., 2003). Therefore, interest in including fertility and functional traits in the breeding goal for dairy cattle populations has increased. Use of direct measures of reproductive efficiency in breeding value prediction programs is currently limited by a number of issues, and the calving interval (CI) is traditionally considered the main fertility indicator during the productive life of dairy cattle (Interbull, 2007). Compared with other measures of fertility such as days from calving to first service, days open, or nonreturn rate, CI is easily recordable as the time between 2 subsequent calvings and is less affected by data quality issues than other fertility traits (Pryce et al., 2000). However, CI might not be the most desirable direct measure of reproductive efficiency to be included in a breeding program. Measures of CI are available only for cows that calve 2 or more times and not for females that, because of reduced fertility, do not calve and are culled. The CI is not an early measure of fertility and it is not an adequate selection tool for breeding organizations, which select bulls on the basis of the earliest information recorded on their female offspring. Consequently, a search for genetic relationships between CI and other traits to be exploited in breeding programs is of interest. Recently, BCS gained interest as an indirect trait for enhancing reproductive performance and robustness of dairy cows (Pryce et al., 2000; Kadarmideen and Wegmann, 2003). Most studies on the relationships between BCS and yield or functional traits have been carried out for Holstein Friesian cattle, whereas for other breeds these relationships have not been reported.

The aim of this study was to estimate genetic parameters for CI, BCS, daily milk (MY), fat (FY), and protein (PY) yield, SCS, and linear type traits for the Italian Brown Swiss population.

\section{MATERIALS AND METHODS}

\section{Data Collection}

The Italian Brown Swiss Association (ANARB) has included appraisal of BCS in the linear type trait classi- 
fication program since September 2002. In that program, scoring for 18 linear type traits and BCS is performed once for all registered first-parity cows, starting $30 \mathrm{~d}$ after calving. Scores for type traits are attributed on the basis of a linear system and range from 1 to 50 , whereas scoring of body condition, which is performed after tactile and visual appraisal of the amount of fat tissue covering the lumbar region of the vertebrae and around the tail head (Edmonson et al., 1989), is based on a 5-point scale with 0.25 -unit increments.

Calving interval was computed as the number of days between the first and the second calving and, for statistical analysis, CI records $<200$ or $>800 \mathrm{~d}$ were discarded. Only BCS records collected between 30 and $360 \mathrm{~d}$ of the first lactation were available for the analysis. The date of BCS record for a cow was matched with the closest test-day milk record. The average number of days between the date of BCS and the closest milk testday was $9.9 \mathrm{~d}(\mathrm{SD}=10.8 \mathrm{~d})$. A test-day milk record included data on MY, FY, PY, and SCS.

A total of 32,359 records on BCS, yield, and linear type traits, and SCS of first-parity Brown Swiss cows reared in 4,885 herds were analyzed. The pedigree file $(96,661$ animals) included animals with a phenotypic record and all their known ancestors.

\section{Estimation of Genetic Parameters}

(Co)variance components were estimated using the VCE package (Groeneveld, 1998) and REML procedures based on multiple-trait animal models. To reduce computer memory requirements, estimation of variance components was performed in eleven 4-trait multivariate analyses that always included CI and BCS in the group of analyzed traits.

In each 4-trait analysis, estimates of (co)variance components were obtained on the basis of the following multivariate linear model:

$$
\left[\begin{array}{l}
\mathbf{y}_{1} \\
\mathbf{y}_{2} \\
\mathbf{y}_{3} \\
\mathbf{y}_{4}
\end{array}\right]=\left[\begin{array}{cccc}
\mathbf{x}_{1} & \mathbf{0} & \mathbf{0} & \mathbf{0} \\
\mathbf{0} & \mathbf{X}_{2} & \mathbf{0} & \mathbf{0} \\
\mathbf{0} & \mathbf{0} & \mathbf{X}_{3} & \mathbf{0} \\
\mathbf{0} & \mathbf{0} & \mathbf{0} & \mathbf{x}_{4}
\end{array}\right] \cdot\left[\begin{array}{l}
\beta_{1} \\
\beta_{2} \\
\beta_{3} \\
\beta_{4}
\end{array}\right]+\left[\begin{array}{cccc}
\mathbf{z}_{1} & \mathbf{0} & \mathbf{0} & \mathbf{0} \\
\mathbf{0} & \mathbf{Z}_{2} & \mathbf{0} & \mathbf{0} \\
\mathbf{0} & \mathbf{0} & \mathbf{Z}_{3} & \mathbf{0} \\
\mathbf{0} & \mathbf{0} & \mathbf{0} & \mathbf{Z}_{4}
\end{array}\right] \cdot\left[\begin{array}{l}
\mathbf{u}_{1} \\
\mathbf{u}_{2} \\
\mathbf{u}_{3} \\
\mathbf{u}_{4}
\end{array}\right]+\left[\begin{array}{l}
\mathbf{e}_{1} \\
\mathbf{e}_{2} \\
\mathbf{e}_{3} \\
\mathbf{e}_{4}
\end{array}\right]
$$

where $\mathbf{y}_{1}$ and $\mathbf{y}_{2}$ were vectors of BCS and CI observations, respectively; $\mathbf{y}_{3}$ and $\mathbf{y}_{4}$ were vectors of observations on 2 other traits, which could be yield traits (MY, FY, or PY), SCS, or linear type traits; $\boldsymbol{\beta}_{1}, \boldsymbol{\beta}_{2}, \boldsymbol{\beta}_{\mathbf{3}}$, and $\boldsymbol{\beta}_{4}$ were unknown vectors of fixed effects; $\mathbf{u}_{1}, \mathbf{u}_{2}, \mathbf{u}_{3}$, and $\mathbf{u}_{4}$ were unknown vectors of random additive genetic effects of animals; $\mathbf{e}_{1}, \mathbf{e}_{2}, \mathbf{e}_{3}$, and $\mathbf{e}_{4}$ were vectors of random residuals; $\mathbf{X}_{1}, \mathbf{X}_{2}, \mathbf{X}_{\mathbf{3}}$, and $\mathbf{X}_{\mathbf{4}}$ were known incidence matrices relating fixed effects in $\boldsymbol{\beta}_{\mathbf{1}}, \boldsymbol{\beta}_{\mathbf{2}}, \boldsymbol{\beta}_{\mathbf{3}}$, and $\boldsymbol{\beta}_{4}$ to $\mathbf{y}_{1}, \mathbf{y}_{2}, \mathbf{y}_{3}$, and $\mathbf{y}_{4}$, respectively; and $\mathbf{Z}_{1}, \mathbf{Z}_{2}, \mathbf{Z}_{3}$, and $\mathbf{Z}_{4}$ were known incidence matrices relating additive genetic effects in $\mathbf{u}_{1}, \mathbf{u}_{2}, \mathbf{u}_{3}$, and $\mathbf{u}_{4}$ to $\mathbf{y}_{1}, \mathbf{y}_{2}, \mathbf{y}_{3}$, and $\mathbf{y}_{4}$, respectively.

For the random terms of the model, the following (co)variance structure was assumed:

$$
\operatorname{Var}\left[\begin{array}{l}
e_{1} \\
e_{2} \\
e_{3} \\
e_{4}
\end{array}\right]=\mathbf{R}=\mathbf{R}_{\mathbf{0}} \otimes \mathbf{I}
$$

and

$$
\operatorname{Var}\left[\begin{array}{l}
u_{1} \\
u_{2} \\
u_{3} \\
u_{4}
\end{array}\right]=\mathbf{G}=\mathbf{G}_{\mathbf{0}} \otimes \mathbf{A}
$$

where

$$
\begin{array}{r}
\mathbf{R}_{\mathbf{0}}=\left[\begin{array}{cccc}
\sigma_{e_{1}}^{2} & \sigma_{e_{1} e_{2}} & \sigma_{e_{1} e_{3}} & \sigma_{e_{1} e_{4}} \\
\sigma_{e_{1} e_{2}} & \sigma_{e_{2}}^{2} & \sigma_{e_{2} e_{3}} & \sigma_{e_{2} e_{4}} \\
\sigma_{e_{1} e_{3}} & \sigma_{e_{2} e_{3}} & \sigma_{e_{3}}^{2} & \sigma_{e_{3} e_{4}} \\
\sigma_{e_{1} e_{4}} & \sigma_{e_{2} e_{4}} & \sigma_{e_{3} e_{4}} & \sigma_{e_{4}}^{2}
\end{array}\right], \\
\mathbf{G}_{\mathbf{0}}=\left[\begin{array}{cccc}
\sigma_{a_{1}}^{2} & \sigma_{a_{1} a_{2}} & \sigma_{a_{1} a_{3}} & \sigma_{a_{1} a_{4}} \\
\sigma_{a_{1} a_{2}} & \sigma_{a_{2}}^{2} & \sigma_{a_{2} a_{3}} & \sigma_{a_{2} a_{4}} \\
\sigma_{a_{1} a_{3}} & \sigma_{a_{2} a_{3}} & \sigma_{a_{3}}^{2} & \sigma_{a_{3} a_{4}} \\
\sigma_{a_{1} a_{4}} & \sigma_{a_{2} a_{4}} & \sigma_{a_{3} a_{4}} & \sigma_{a_{4}}^{2}
\end{array}\right],
\end{array}
$$

I was an identity matrix of appropriate order, $\mathbf{A}$ was the numerator of Wright's relationship matrix, $\sigma_{e_{1}}^{2}$, $\sigma_{e_{2}}^{2}, \sigma_{e_{3}}^{2}$ and $\sigma_{e_{4}}^{2}$ were residual variance components, $\sigma_{a_{1}}^{2}, \sigma_{a_{2}}^{2}, \sigma_{a_{3}}^{2}$, and $\sigma_{a_{4}}^{2}$ were additive genetic variance components, $\sigma_{e_{1} e_{2}}, \sigma_{e_{1} e_{3}}, \sigma_{e_{1} e_{4}}, \sigma_{e_{2} e_{3}}, \sigma_{e_{2} e_{4}}$, and $\sigma_{e_{3} e_{4}}$ were residual covariance components, and $\sigma_{a_{1} a_{2}}, \sigma_{a_{1} a_{3}}, \sigma_{a_{1} a_{4}}, \sigma_{a_{2} a_{3}}$, $\sigma_{a_{2} a_{4}}$, and $\sigma_{a_{3} a_{4}}$ were additive genetic covariance components.

The fixed effects in $\boldsymbol{\beta}_{\mathbf{1}}$ for analysis of BCS records were the effects of herds (4,885 herds), year-month of calving (36 levels), age at calving (class 1: $<840 \mathrm{~d}$, class 2: from 841 to $940 \mathrm{~d}$, class 3: from 941 to $1,040 \mathrm{~d}$, class 4: $>1,040 \mathrm{~d}$ ), milk yield (class $1:<18 \mathrm{~kg} / \mathrm{d}$, class 2 : from 18 to $22 \mathrm{~kg} / \mathrm{d}$, class 3 : from 22 to $26 \mathrm{~kg} / \mathrm{d}$, class 4 : $>26$ $\mathrm{kg} / \mathrm{d}$ ), the classifier (37 classifiers), and DIM at scoring (class 1: $<60 \mathrm{~d}$, class 2: from 61 to $90 \mathrm{~d}$, class 3: from 
Table 1. Means and standard deviations of calving interval, BCS, SCS, yield, and linear type traits (scored from 1 to 50 points)

\begin{tabular}{lccll}
\hline & & & \multicolumn{2}{c}{ Type trait score } \\
\cline { 3 - 4 } & Mean & SD & 1 & 50 \\
\hline Calving interval, d & 421.0 & 86.0 & & \\
BCS & 3.20 & 0.35 & & \\
Milk yield, kg/d & 22.3 & 5.60 & & \\
Fat yield, kg/d & 0.86 & 0.26 & & \\
Protein yield, kg/d & 0.76 & 0.20 & & \\
SCS & 2.22 & 2.05 & Small & Tall \\
Stature & 31.85 & 8.02 & Narrow & Wide \\
Strength & 25.75 & 8.19 & Shallow & Deep \\
Body depth & 28.90 & 7.22 & Coarse & Angular \\
Angularity & 26.78 & 7.40 & Weak & Low pins \\
Top line & 24.77 & 4.58 & High pins & Wide \\
Rump angle & 25.79 & 5.36 & Narrow & Sickled \\
Thurl width & 23.37 & 7.03 & Postly & Modeled \\
Rear leg set & 26.90 & 7.07 & Woarse & Strong \\
Hock quality & 23.42 & 8.07 & Low & Tight \\
Pastern & 24.61 & 8.56 & Loose & High \\
Heel height & 23.77 & 8.50 & Low & Wide \\
Fore udder attachment & 24.30 & 8.77 & Narrow & Strong \\
Rear udder height & 24.37 & 7.09 & Broken & Deep \\
Rear udder width & 28.85 & 10.06 & Shallow & Converge \\
Udder support & 26.06 & 7.83 & Diverge & Long \\
Udder depth & 27.98 & 7.59 & Short & \\
Teat direction & 25.21 & 6.37 & & \\
Teat length & 26.82 & 7.47 & & \\
& & & & \\
& & & & \\
\end{tabular}

91 to $120 \mathrm{~d}$, class 4: from 121 to $150 \mathrm{~d}$, class 5: from 151 to $180 \mathrm{~d}$, class 6: from 181 to $210 \mathrm{~d}$, class 7: from 211 to 240 d, class 8: from 241 to $270 \mathrm{~d}$, class 9: $>270 \mathrm{~d}$ ).

For analysis of CI, $\boldsymbol{\beta}_{2}$ included the fixed effects of herds, year-month of calving, and age at calving only. The models used for analysis of yield traits (MY, FY, or PY) and SCS accounted for the same fixed effects considered for CI, but included also a DIM class effect (10 monthly classes, class 1 : from 5 to $30 \mathrm{~d}$, class 10: $>270 \mathrm{~d}$ ). The fixed effects considered in the analysis of linear type traits were the same effects taken into account for BCS with the exception of the milk yield class effect and the addition to the model, for udder traits only, of the effects of the time interval between the last milking and the occurrence of the linear type scoring.

\section{RESULTS}

\section{Descriptive Statistics}

Descriptive statistics for analyzed traits are presented in Table 1. Mean and standard deviations for CI were 420 and $86 \mathrm{~d}$, respectively, indicating a relatively poor fertility condition in Italian Brown Swiss cattle. Average BCS was 3.20 and its coefficient of variation was nearly half that of MY (11 vs. $25 \%$, respectively). The distribution of BCS approximated a sym- metrical distribution (Figure 1), with 3.25 being the most frequent score and scores $<2.50$ or $>4.00$ being very rare. Average test-day MY, FY, and PY were 22.3, 0.86 , and $0.76 \mathrm{~kg} / \mathrm{d}$, respectively, which corresponds to $3.86 \%$ fat and $3.41 \%$ protein and is in agreement with previous estimates for the Italian Brown Swiss population. Cumulative 305-d lactation milk yield averaged $7,000 \mathrm{~kg}$ and was similar to figures reported for the Italian Brown Swiss cattle population based on all available test-day records (AIA, 2006). Averages and standard deviations for linear type traits ranged from 23 to 32 and from 4.6 to 10.1 , respectively.

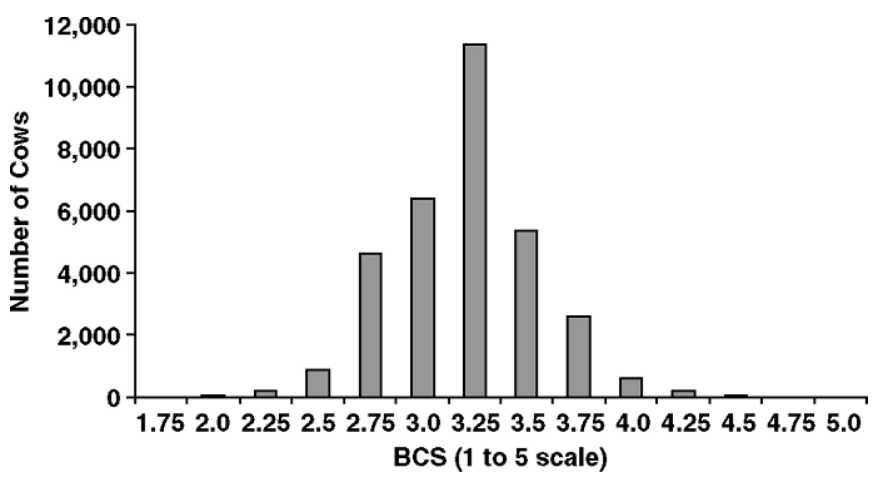

Figure 1. Distribution of BCS. 
Table 2. Heritability estimates of SCS, yield and linear type traits and genetic correlations with calving interval (CI) and BCS $^{1}$

\begin{tabular}{lcrr}
\hline & & \multicolumn{2}{c}{ Genetic correlation } \\
\cline { 3 - 4 } Item & $\mathrm{h}^{2}$ & $\mathrm{CI}$ & $\mathrm{BCS}$ \\
\hline Calving interval (CI), d & 0.05 & - & - \\
BCS & 0.15 & -0.35 & - \\
Milk yield, kg/d & 0.14 & 0.56 & -0.40 \\
Fat yield, kg/d & 0.09 & 0.53 & -0.31 \\
Protein yield, kg/d & 0.13 & 0.55 & -0.22 \\
SCS & 0.06 & 0.19 & -0.26 \\
Stature & 0.32 & 0.15 & -0.18 \\
Strength & 0.17 & 0.17 & 0.22 \\
Body depth & 0.10 & 0.41 & -0.18 \\
Angularity & 0.19 & 0.46 & -0.87 \\
Top line & 0.10 & 0.06 & -0.80 \\
Rump angle & 0.24 & -0.01 & 0.11 \\
Thurl width & 0.14 & 0.43 & -0.29 \\
Rear leg set & 0.14 & 0.12 & -0.39 \\
Hock quality & 0.08 & 0.19 & -0.73 \\
Pastern & 0.09 & -0.09 & 0.19 \\
Heel height & 0.07 & 0.03 & 0.35 \\
Fore udder attachment & 0.14 & 0.42 & -0.31 \\
Rear udder height & 0.17 & 0.26 & -0.58 \\
Rear udder width & 0.17 & 0.50 & -0.47 \\
Udder support & 0.13 & 0.15 & -0.27 \\
Udder depth & 0.23 & -0.21 & -0.07 \\
Teat direction & 0.15 & 0.17 & -0.29 \\
Teat length & 0.32 & 0.03 & 0.10 \\
\hline
\end{tabular}

${ }^{1}$ Standard errors of heritability estimates ranged from 0.006 to 0.017; standard errors of genetic correlation estimates ranged from 0.006 to 0.076 .

\section{Heritability of Traits}

Estimates of heritability and genetic correlations between CI or BCS and all other traits are reported in Table 2. Because estimated parameters were obtained in a set of eleven 4-trait multivariate analyses with BCS and CI always included in the group of analyzed traits, heritabilities presented in Table 2 for BCS and CI are averages of 11 estimates. Standard errors of estimates were lower than 0.017 for all investigated traits. The calving interval was the trait exhibiting the smallest estimate of heritability $\left(\mathrm{h}^{2}=0.05\right)$, which was similar to the estimate obtained for SCS. Heritability of BCS was moderate $\left(\mathrm{h}^{2}=0.15\right)$ and comparable to those obtained for MY and PY. These traits exhibited estimates of heritability greater than that obtained for FY.

Within the group of linear type traits, heel height, hock quality, and pastern exhibited the lowest estimated heritabilities, which ranged from 0.07 to 0.09 , whereas the largest estimates were obtained for stature and teat length. The range of estimated heritability was from 0.13 to 0.32 for udder traits, from 0.07 to 0.14 for foot and leg traits, and from 0.10 to 0.32 for traits related to body size.

\section{Genetic Correlations}

Genetic correlations (Table 2) between BCS and yield traits were negative and ranged from -0.20 to -0.40 , indicating that an increased genetic merit for MY, FY, or PY would result in a correlated decrease of BCS in long-term selection programs. Also, unfavorable estimates ranging from 0.53 to 0.56 were obtained for the genetic correlations between fertility (measured as CI) and yield traits. The estimated genetic correlation between BCS and CI was -0.35 , indicating a moderately negative genetic association for these traits. The genetic correlation between SCS and BCS or CI was moderate, negative for BCS $(-0.26)$ and positive for CI $(0.19)$.

Most linear type traits exhibited estimates of genetic correlations with BCS $>0.15$, with the exception of rump angle, udder depth, and teat length. Body condition score was moderately and positively associated with pastern, strength, and heel height and exhibited negative genetic correlations ranging from moderate to large with all other type traits. The magnitude of correlations of CI with type traits was comparable with that of the relationships between type traits and BCS, but, in general, the direction of these correlations was opposite. Angularity was the trait with the greatest genetic correlation with BCS $(-0.87)$ and was also correlated with a longer CI (0.46).

\section{DISCUSSION}

Body condition score has been proposed as a possible indicator trait for fertility (Pryce et al., 2000, 2001; Royal et al., 2002). In Italy, this trait has been included in both programs for linear type-traits classification arranged by the Italian Brown Swiss Association and by the Italian Holstein-Friesian Association. Body condition scores of Brown Swiss first-parity cows were on average greater and less variable than those attributed to Holstein-Friesian cows during the first lactation (Pryce et al., 2002; Kadarmideen and Wegmann, 2003). The greater BCS average observed for Brown Swiss cows compared with Holsteins is likely to be associated with differences in average milk yield of these breeds.

\section{Heritability of Traits}

Heritability of BCS estimated in this study was similar to values reported by Dechow et al. (2002, 2003) and Kadarmideen and Wegmann (2003), but different in magnitude when compared with estimates obtained in others studies (Pryce et al., 2001; Banos et al., 2004; Pryce and Harris, 2006). These discrepancies may be attributed to differences across studies in scales used for scoring of body condition, statistical model definition, breeds involved, number of available records per 
animal, accuracy and consistency among evaluators, and data editing procedures.

The estimated heritability for CI was small and similar to most literature estimates of heritability for fertility traits (Pryce et al., 2000, 2002). This finding, a number of unfavorable features for CI (e.g., CI is available only for the most fertile cows that calve 2 or more times and not for the culled ones, it is not an early measure of fertility, it is not an adequate selection tool for breeding organizations) as a selection trait, and difficulties related to the limited reliability of recorded information on fertility traits different from CI support the relevance of investigations searching for traits genetically related to fertility and of potential use in breeding programs.

Heritability estimates obtained for MY, FY, and PY were slightly lower than those reported in other studies (Pryce et al., 2000; Kadarmideen and Wegmann, 2003; Pryce and Harris, 2006). Such differences are likely attributable to the analysis of a single test-day yield record instead of multiple test-day records extrapolated to lactation yields.

For linear type traits, estimated heritabilities were similar to those used in breeding values estimation routine by the Italian Brown Swiss Association (Interbull, 2007) and are consistent with estimates obtained for Holstein-Friesian cattle populations (Cassandro et al., 1997; Pryce et al., 2000; Kadarmideen and Wegmann, 2003).

\section{Relationships of BCS or Cl with Yield and SCS}

The genetic relationships of BCS or CI with yield traits were moderately negative and positive, respectively, and comparable in magnitude and direction to estimates reported in other studies (Pryce et al., 2000; Berry et al., 2002; Dechow et al., 2002). Enhancement of MY, FY, and PY through selection is expected to decrease BCS and to increase CI. Pryce et al. (2000) and Gallo et al. (2001) have both indicated that the level of milk production is unfavorably related to fertility and BCS. Dairy cows use body reserves as a source of energy to sustain production in early lactation (Pryce and Løvendahl, 1999). Because of negative energy balance due to inadequate feed intake in early lactation, it is likely that selection to enhance milk yield has led to a greater dependence on body tissue mobilization to sustain milk production (Veerkamp, 1998). Cows with high genetic merit for milk yield are likely to exhibit marked body tissue mobilization, with increasing risk of impairment of reproductive performance (Pryce et al., 2001).

Results of this study provide evidence of unfavorable genetic relationships between BCS and fertility for the
Italian Brown Swiss cattle population and are consistent with results of investigations on Holstein-Friesian cows (Pryce et al., 2000, 2001, 2002; Dechow et al., 2002; Wall et al., 2003; Banos et al., 2004), albeit that Brown Swiss cows exhibited greater body condition than did Holstein-Friesian cows in other studies. Excess of body tissue mobilization in early lactation, caused by negative energy balance, has been associated with a greater incidence of metabolic disorders and poor fertility (Dechow et al., 2002). From a genetic point of view, cows with low BCS may lack sufficient energy reserves to activate ovarian function or display estrous. The unfavorable genetic correlations between BCS and production and between BCS and fertility might also be associated with body tissue mobilization closely linked to genes controlling fertility of dairy cows or exhibiting pleiotropic effects on fertility traits (Berry et al., 2002).

Genetic correlations of CI or BCS with SCS were low or moderate. The sign and magnitude of these estimates are similar to those reported by Lassen et al. (2003), Wall et al. (2003), and Pryce and Harris (2006) and confirm indications by Dechow et al. (2004) who observed a negative genetic correlation between BCS and mastitis incidence. Because in many countries the breeding goal for dairy cattle populations aims to reduce SCS, a correlated positive effect on fertility and body condition of cows is expected.

\section{Relationships of $\mathrm{BCS}$ or $\mathrm{Cl}$ with Type Traits}

The magnitude and direction of the genetic relationships between BCS or CI and several type traits obtained in this study were similar to those reported in the literature (Veerkamp and Brotherstone, 1997; Pryce et al., 2000, 2001; Dechow et al., 2003). In general, the relationships for BCS and CI were of opposite sign. In this study, CI and BCS showed moderate positive (CI) and moderate negative (BCS) genetic relationships with stature, respectively. A similar result was obtained by Pryce et al. (2000) for the genetic relationship between CI and stature and by Veerkamp and Brotherstone (1997) for BCS and stature, but not by Dechow et al. (2003), who reported a positive genetic association between stature and BCS. For body depth and thurl width, genetic correlations with CI were positive but of greater magnitude than the one for stature, indicating that cows exhibiting greater body depth and larger thurl width have longer CI. Correlations of these type traits with BCS were smaller than the correlations with CI.

Selection for greater angularity will unfavorably affect CI and BCS of cows. Pryce et al. (2000) and Wall et al. (2005) reported similar relationships between an- 
gularity and CI. Compared with CI, the genetic relationship between BCS and angularity was of opposite sign and of greater magnitude. Unfavorable genetic associations between BCS and angularity, ranging from -0.47 to -0.77 , have been reported by a number of studies on other dairy cattle populations (Veerkamp and Brotherstone, 1997; Dechow et al., 2003, 2004; Lassen et al., 2003; Kadarmideen and Wegmann, 2003).

Fore udder attachment and rear udder height and width were type traits that exhibited positive genetic correlations with CI, suggesting that cows with good udders (i.e., with higher scores for udder traits) have longer CI. Positive genetic correlations between udder traits and CI might therefore result in more opportunities to conceive given to cows with better udder morphology and functional characteristics (Pryce et al., 2000; Wall et al., 2005) and it is also likely that the relationship with milk yield plays an important role. For BCS, negative genetic correlations were found with udder depth, udder support, fore udder attachment, and rear udder height and width, as in the studies by Veerkamp and Brotherstone (1997) and Kadarmideen and Wegmann (2003). Within these traits, rear udder height and width were the traits showing the greatest genetic correlation with BCS.

Rear leg set and hock quality were moderately negatively correlated with BCS, indicating that cows with higher BCS are expected to have straighter legs and lower hock quality than thinner cows. Similar results were found by Dechow et al. (2003).

Measures of fertility are difficult to collect and exhibit low heritability, but are genetically correlated with traits that are more heritable and can be recorded with greater reliability such as BCS, yield, and some linear type traits. Hence, these traits are natural candidates as indirect traits for improving fertility of dairy cattle and to support the prediction of genetic merit for fertility. The use of yield, BCS, and type traits is beneficial because it can help to overcome problems related to incorrect registrations that may be present in fertility data (Wall et al., 2003). In comparison with other traits related to fertility, BCS has the advantage of being more acceptable for dairy producers who are unlikely to support a breeding program aimed to enhance fertility through selection for reduced yields, angularity, or other type traits like body depth, thurl width, fore udder attachment, and width. If assessment of body condition is performed only once and exclusively for first-parity cows, recording schemes should consider that BCS in early lactation exhibits the strongest relationship with CI (Pryce et al., 2000).

\section{CONCLUSIONS}

Body condition score and its relationships with fertility, yield, and type traits in first-parity Brown Swiss cows were analyzed. Due to low heritability, lack of records for culled cows, and late availability of information, relying exclusively on direct selection to reduce CI is not advisable. Indirect selection for improved fertility might rely on BCS and a number of linear type traits. On the basis of the estimated genetic parameters, use of BCS and type traits for indirect selection for enhanced fertility in dairy cows is expected to be more effective than direct selection for fertility based on measurement of CI. Indeed, those traits are more heritable than CI, allow earlier prediction of bulls' breeding values, and provide information for cows that do not have the opportunity for a further calving.

\section{ACKNOWLEDGMENTS}

The authors gratefully acknowledge the Italian Brown Swiss Association (ANARB) for its contribution to this study. This research was supported by Trento Province and Superbrown Consortium of Bolzano and Trento, Italy.

\section{REFERENCES}

AIA (Associazione Italiana Allevatori). 2006. Bollettino dei controlli funzionali del latte. AIA, Rome, Italy.

Berry, D. P., F. Buckley, P. Dillion, R. D. Evans, M. Rath, and F. Veerkamp. 2002. Genetic parameters of body condition score and body weight in dairy cows. J. Dairy Sci. 85:2030-2039.

Banos, G., S. Brotherstone, and M. Coffey. 2004. Evaluation of body condition score measured throughout lactation as an indicator of fertility in dairy cattle. J. Dairy Sci. 87:2669-2676.

Cassandro, M., P. Carnier, F. Canavesi, F. Miglior, and G. Bittante. 1997. Stima di parametri genetici tra caratteri produttivi e morfologici e risposta alla selezione di indici aggregati nella razza Frisona. Pages 97-98 in Proc. XII Natl. Congr. Sci. Assoc. Anim. Prod., Pisa, Italy. Centro Stampa Università di Pisa, Italy.

Castillo-Juarez, H., P. A. Oltenacu, R. W. Blake, C. E. McCulloch, and E. G. Cienfuegos-Rivas. 2000. Effect of herd environment on genetic and phenotypic relationships among milk yield, conception rate and somatic cell score in Holstein cattle. J. Dairy Sci. 83:807-814.

Dechow, C. D., G. W. Rogers, and J. S. Clay. 2002. Heritability and correlations among body condition score loss, body condition score, production and reproductive performance. J. Dairy Sci. 85:3062-3070.

Dechow, C. D., G. W. Rogers, L. Klei, and T. J. Lawlor. 2003. Heritability and correlations among body condition score, dairy form, and selected linear type traits. J. Dairy Sci. 86:2236-2242.

Dechow, C. D., G. W. Rogers, U. Sander-Nielsen, L. Klei, T. J. Lawlor, J. S. Clay, A. E. Freeman, G. Abdel-Azim, A. Kuck, and S. Schnell. 2004. Correlations among body condition scores from various sources, dairy form, and cow health from the United States and Denmark. J. Dairy Sci. 87:3526-3533.

Dematawewa, C. M. B., and P. J. Berger. 1998. Genetic and phenotypic parameters for 305-day yield, fertility and survival in Holsteins. J. Dairy Sci. 81:2700-2709.

Edmonson, A. J., J. Lean, L. D. Weaver, T. Farver, and G. Webster. 1989. A body condition scoring chart for Holstein dairy cows. J. Dairy Sci. 77:68-78.

Gallo, L., P. Carnier, M. Cassandro, R. Dal Zotto, and G. Bittante. 2001. Test-day genetic analysis of condition score and heart girth in Holstein Friesian cows. J. Dairy Sci. 84:2321-2326.

Groeneveld, E. 1998. REML VCE: A multivariate multi model restricted maximum likelihood (co)variance component estimation 
package. Version 4 User's guide. Institute of Animal Husbandry and Animal Behaviour, Mariansee, Germany.

Grosshans, T., Z. Z. Xu, L. J. Burton, D. L. Johnson, and K. L. Macmillan. 1997. Performance and genetic parameters for fertility of seasonal dairy cows in New Zealand. Livest. Prod. Sci. 51:41-51.

Kadarmideen, H. N., and S. Wegmann. 2003. Genetic parameters for body condition score and its relationship with type and production traits in Swiss Holsteins. J. Dairy Sci. 86:3685-3693.

Interbull. 2007. National Evaluation Systems Information. http:// www-interbull.slu.se/national_ges_info2/framesida-ges.htm. Accessed August 2007.

Lassen, J., M. Hansen, M. K. Sørensen, G. P. Aamand, L. G. Christensen, and P. Madsen. 2003. Genetic relationship between body conditions score, dairy character, mastitis, and diseases other than mastitis in first-parity Danish Holstein cows. J. Dairy Sci. 86:3730-3735

Pryce, J. E., and P. Løvendahl. 1999. Options to reduce vulnerability to metabolic stress by genetic selection. Pages 119-128 in Metabolic Stress in Dairy Cows. J. D. Oldham, G. Simm, A. F. Groen, B. L. Nielsen, J. E. Pryce, and T. L. J. Lawrence, ed. Br. Soc. Anim. Sci. Occ. Publ. No. 24. Br. Soc. Anim. Sci., Edinburgh, UK.

Pryce, J. E., M. P. Coffey, and S. Brotherstone. 2000. The genetic relationship between calving interval, body condition score and linear type and management traits in registered Holsteins. J. Dairy Sci. 83:2664-2671.

Pryce, J. E., M. P. Coffey, S. Brotherstone, and J. A. Woolliams. 2002. Genetic relationships between calving interval and body condition score conditional on milk yield. J. Dairy Sci. 85:1590-1595.
Pryce, J. E., M. P. Coffey, and G. Simm. 2001. The relationship between body condition score and reproductive performance. J. Dairy Sci. 84:1508-1515.

Pryce, J. E., and B. L. Harris. 2006. Genetics of body condition score in New Zealand dairy cows. J. Dairy Sci. 89:4424-4432.

Rogers, G. W., G. Banos, and U. Sander-Nielsen. 1999. Genetic correlations among protein yield, productive life, and type traits from the United States and diseases other than mastitis from Denmark and Sweden. J. Dairy Sci. 82:1331-1338.

Royal, M. D., J. E. Pryce, J. A. Woolliams, and A. P. E. Flint. 2002 The genetic relationship between commencement of luteal activity and calving interval, body condition score, production, and linear type traits in Holstein-Friesian dairy cattle. J. Dairy Sci. 85:3071-3080.

Simianer, H., H. Solbu, and R. L. Schaeffer. 1991. Estimated genetic correlations between disease and yield traits in dairy cattle. J. Dairy Sci. 74:4358-4365.

Veerkamp, R. F. 1998. Selection for economic efficiency of dairy cattle using information on live weight and feed intake: A review. J. Dairy Sci. 81:1109-1119.

Veerkamp, R. F., and S. Brotherstone. 1997. Genetic correlations between linear type traits, food intake, live weight and condition score in Holstein Friesian dairy cattle. Anim. Sci. 64:385-392.

Wall, E., S. Brotherstone, and J. A. Woolliams. 2003. Genetic evaluation of fertility using direct and correlated traits. J. Dairy Sci. 86:4093-4102.

Wall, E., I. M. S. White, M. P. Coffey, and S. Brotherstone. 2005. The relationship between fertility, rump angle, and selected type information in Holstein-Friesian cows. J. Dairy Sci. 88:15211528 . 